research spending.

The present crisis may tempt the government to cut back on all research, which Jens Reich, a molecular biologist and member of New Forum, believes would be disastrous by prompting East German scientists to sell their services to the highest bidder. West Germany, the most likely outlet, might then come to rely on East German laboratories for routine or labour-intensive measurements. Already it is reported that East German medical patients have been offered to West German pharmaceutical companies for tests of new drugs.

Would East German researchers really sell out in ways like this if support started to dry up? Reich says, "I only know the scientific community here as frustrated and cowardly, so I am not sure how alert they are to this danger". Reich also sees danger in the "robberbaron" mentality that might take over if East German researchers were forced to compete for the little hard currency available.

New Forum is only slowly learning of others' efforts to restructure institutes. Groups of researchers seem to be meeting independently in living rooms across East Germany to discuss restructuring of their institutes. Eventually, New Forum, may coordinate these discussions, but separate groups seem to be thinking along similar lines.

Dietrich Koch, a specialist in artificial intelligence, has led a group planning a new structure for the Central Institute for Cybernetics and Information Processing at which he works. The plan, put forward on 30 October, is already being put into practice in the vacuum formed by the abolition last week of the Academy statute, the legal basis for the organization of institutes within the academy.

Instead, there is now an institute council to give researchers and technical personnel a say in important decisions previously made by the director or handed down from above, including the choice of topics for investigation and allocation of funds between them.

The weak point in the plan, Koch admits, is the future role of the director. If a director should refuse to accept a diminished role or to cooperate with the changes, there could be trouble. Fortunately, Koch says, the director of his own institute has played a leading part in the reforms. "We all thought he was much more calcified than he has turned out to be."

Koch also proposes that the guaranteed funds that all institutes are used to receiving should be eliminated, a change that may meet resistance from researchers. "The old system stifles creativity", he says, since department heads considered new projects proposed by underlings too risky.

Koch and the others even so agree that there must be a basis of socialism in any new structure of East German research. They say that their views enjoy broad support from researchers of all ages. "If we don't do something different from the West, we might as well all go to West Germany.

Steven Dickman

\title{
Rumours of trouble denied
}

\section{Washington}

Although the House of Representatives and the Senate finally agreed this year to authorize $\$ 225$ million to start building the Superconducting Super Collider (SSC), the $20 \mathrm{TeV}, 53$-mile circumference proton-proton accelerator, the highenergy physics community and interested politicians still evidently feel that the project's future is somewhat precarious. This nervousness last week led Representative Joe Barton (Republican-Texas), whose district includes Waxahachie, the proposed site of the SSC, to pay a visit to the Department of Energy (DoE) and hold a press briefing with the aim of calming fears of cost over-runs and technical difficulties hinted at in an otherwise insubstantial story in the Washington Post.

The gist of the newspaper story was that SSC director Roy Schwitters had asked the DoE for as much as $\$ 2,000$ million over the estimated cost of $\$ 5,900$ million to modify and augment the SSC in order to overcome technical troubles with the prototype superconducting magnets. There was also a suggestion that SSC physicists wanted to redesign the injector for the main accelerator ring: in the conceptual SSC design, now four years old, the injector was to feed protons at $1 \mathrm{TeV}$ into the main ring, which would boost them to $20 \mathrm{TeV}$; now, according to the Washington Post, the plan was to raise the injection energy to $2 \mathrm{TeV}$, easing the task of the main ring magnets.

But Barton, after talking to Schwitters and Deputy Energy Secretary W. Henson Moore, said flatly that there had been no request for extra money, and that a change in the injection energy was merely one of a number of ideas that were being considered in adapting the conceptual design to a final design specific to the Waxahachie site. Barton added that there was also a possibility of reducing the length of the main ring magnets from 17 metres to 12 , but that this was being considered, among other reasons, because shorter magnets would be easier to install.

Little of this is in fact new. Even when the conceptual design was released, there was talk of changing the injector energy to 2 TeV. SSC spokesman Russ Wylie said that this option had received extra support from computer simulations which indicated that a higher injection energy would improve beam quality. And he added that although the first prototypes of the main ring magnets did not produce a magnetic field of sufficiently high uniformity, later models were doing well. He emphasized that the magnet design is still changeable, and will be made final only in a year or two, after collaborative work with the companies that will mass-produce the thousands of magnets needed.

The \$225 million authorized for this financial year is being partially held back by the DoE until it has approved sitespecific SSC design, which Schwitters hopes will be ready by the end of the year. Both Wylie and a DoE spokesman agreed that the advertized cost ceiling of $\$ 5,900$ million was a solid one, and that changes in the injector, for example, are unlikely to win DoE approval, no matter how good the technical arguments, if they increase the cost.

Although, according to Barton, the Post story set off no political fires, he and others were evidently anxious to stamp out the smouldering rumours before they had a chance to flare up.

But the incident did bring out from several quarters official declarations that the SSC will come in at or below budget, statements which may haunt Schwitters and others should the design changes now being pondered belie more serious problems than have been publicly admitted.

David LIndley LASER TECHNOLOGY

\section{Tamper-proof passport on the way}

\section{Sydney}

Australia is about to begin marketing a counterfeit-proof passport. The Department of Foreign Affairs and Trade has developed a laser-printing technique and a special plastic laminate to make what they claim is the world's finest tamper-proof document.

In a conventional laminated passport, the photograph is attached to a page and sealed on by a plastic screen, but the screen can be removed and a new photograph inserted. In the new technique, which works only in black and white, photographic images and other details are printed by laser onto an adhesive reversed- image film, which is then ingrained into the glue of the passport laminate.

The Australian government, according to director of passports Ted Radclyffe, has taken out a provisional patent on the process, and a licensing agreement has been signed with the $3 \mathrm{M}$ company and Gestetner, developers of the laser printer. Radclyffe says that the United States, New Zealand and Singapore are likely to be early investors and that with expanding markets worldwide for other security printing applications, such as drivers' licenses and identity cards, the technique is "likely to make Australia a lot of money".

Tania Ewing 